\title{
„NIEPOPRAWNY RECYDYWISTA”. KRAJOWY KORESPONDENT „NARODOWCA” ADAM CZEKALSKI
}

\author{
Krzysztof TARKA (Opole)
}

13 czerwca 1958 roku w Toruniu przed Zamiejscowym Ośrodkiem Sądu Wojewódzkiego rozpoczął się proces przeciwko Adamowi Czekalskiemu. Wiceprokurator wojewódzki B. Langner zarzucał mu, że od listopada 1956 roku do maja następnego roku przesyłał do dziennika „Narodowiec” ukazującego się w Lens we Francji „różne artykuły dotyczące życia gospodarczego i politycznego w kraju, w których lżył i wyszydzał ustrój Państwa Polskiego""1.

Czekalski uważał, że przesyłając korespondencje do „Narodowca” nie popełnił żadnego przestępstwa. Artykuły wysyłał legalnie, pocztą, na adres mieszkającego we Francji Tadeusza Piskorskiego, który następnie przekazywał je redakcji emigracyjnego dziennika. Za opublikowane teksty parokrotnie otrzymał lekarstwa, paczki z odzieżą i żywnością oraz „trochę pieniędzy”. Podczas procesu podkreślał, że w swoich artykułach pozytywnie oceniał przemiany w kraju po Październiku 1956 roku. Odpowiadając na zarzuty prokuratora wyjaśniał:

Ma pan prokurator rację, że Czekalski robi porachunki z przeszłością i że ma pretensje do Polski Ludowej, ale z pewnym sprostowaniem. Mnie chodzi nie o Polskę Ludową i nie do niej mam pretensję, ale do tyrańskiego systemu rządzenia w dwunastoleciu [1944-1956] i do tego systemu mam i będę miał pretensję. A krytykując ten system, równocześnie ukazuję nadchodzenie lepszego jutra. Piszę przecież, że po październiku [1956 roku] człowiek czuje się wolnym, może wszystko mówić i nikt go nie tropi. Czyż takie pokazanie prawdy — pytał oskarżony — może być szkodliwą działalnością za

${ }^{1}$ Archiwum Instytutu Pamięci Narodowej, Delegatura w Bydgoszczy [dalej: AIPN By.], sygn. 044/288, t. 2, k. 149, Odpis wyroku sądu przeciwko A. Czekalskiemu z 16 VI 1958. 
granicą? Jeżeli twierdzę, że jest o wiele lepiej niż było, to gdzież tu jakieś szkalowanie ${ }^{2}$

W swoich artykułach Czekalski wielokrotnie odwoływał się do informacji opublikowanych w krajowej prasie. Jego pierwszy tekst Na gruzach kłamstwa, oparty na dokumentach VIII plenum KC PZPR z października 1956 roku opublikowanych w „Nowych Drogach", w grudniu 1958 roku został nadany przez Polskie Radio (Czekalski otrzymał nawet honorarium autorskie): „Jeżeli się dzisiaj mnie oskarża - stwierdził podczas procesu - to obok mnie powinni również zasiadać tutaj i koledzy z Radia"3. Broniąc się przed sądem podkreślił, iż krytycznie przedstawiał „tylko okres do października, natomiast to wszystko, co się działo po październiku, omawiałem absolutnie wszystko pozytywnie".

Ja nie jestem przeciwnikiem Polski Ludowej, ani ustroju demokracji ludowej — dodał oskarżony - ale jestem przeciwnikiem tego wszystkiego, co było u nas do października. Nie jestem przeciwnikiem komunizmu, ale stalinizmu, a to uważam za różnicę zasadniczą ${ }^{4}$.

Korespondent „Narodowca” przekonywał, że jego zamiarem nie było lżenie czy szkodzenie narodowi polskiemu: „Stoję na stanowisku, że socjalizm sprawiedliwy i wolny odpowiada każdemu rozsądnemu człowiekowi”. Zaznaczył także, że na 82 teksty jakie wysłał do „Narodowca” prokurator w swoim wystąpieniu powołał się zaledwie na siedem z nich: „Oznacza to więc, że pan sam 75 tych artykułów uznał za pozytywne”. W ostatnim słowie, prosząc o uniewinnienie, podkreślił: „Nie poczuwam się do żadnej winy. Pisałem tylko prawdę, a za prawdę nie powinno się człowieka karać"5.

Trzy dni później zapadł wyrok. Sędzia Zygmunt Kubrycht skazał korespondenta „Narodowca" na trzy lata więzienia, utratę praw publicznych i obywatelskich na okres dwóch lat oraz obciążył go kosztami postępowania sądowego ${ }^{6}$.

Adam Czekalski był prawdopodobnie pierwszą osobą sądzoną po Październiku 1956 roku za utrzymywanie kontaktów z emigracyjnym czasopismem i publikowanie artykułów zagranicą ${ }^{7}$. Za podobne „przestępstwo” był już zresztą skazany kilka lat wcześniej. Mimo wcześniejszych represji ponownie nawiązał współpracę z „Narodowcem”. Dziś jest postacią nieznaną i niemal całkowicie zapomnianą, a przecież okazał się być człowiekiem z charakterem, którego nie złamał kilkuletni pobyt w komunistycznym więzieniu i groźba kolejnego procesu.

Kim był Adam Czekalski? Urodził się 14 listopada 1902 roku w Galowie na Kielecczyźnie w rodzinie wiejskiego kowala. W roku 1920 ukończył gimnazjum w Pińczowie. W tym samym roku został wcielony wojska. Służbę wojskową odbywał

\footnotetext{
${ }^{2}$ Przebieg komunistycznego procesu przeciw Adamowi Czekalskiemu krajowemu korespondentowi „Narodowca”, Narodowiec 1959 nr 2, s. 1. Zob. też: AIPN By., 044/288, t. 2, k. 141148, Notatka służbowa ppor. Józefa Łukasiewicza z 17 VI 1958 r. dotycząca przebiegu rozprawy sądowej w sprawie A. Czekalskiego.

${ }^{3}$ Przebieg komunistycznego procesu

${ }^{4}$ Tamże.

${ }^{5}$ Tamże

${ }^{6}$ AIPN By., sygn. 044/288, t. 2, k. 149, Odpis wyroku sądu przeciwko A. Czekalskiemu z 16 VI 1958.

${ }^{7}$ Nieco później, w lipcu 1958 roku, za podobne „przestępstwo” na trzy lata skazana została Hanna Rewska (prokurator oskarżył ją o utrzymywanie korespondencyjnych kontaktów z Jerzym Giedroyciem, przekazanie mu szeregu materiałów oraz kolportaż „Kultury” w Polsce); zob.: A. Friszke, Sprawa Hanny Rewskiej, Zeszyty Historyczne 1996 z. 117, s. 185-191.
} 
w szkole podchorążych w Poznaniu. Na początku 1921 roku został przeniesiony do batalionu zapasowego w Wilnie. Tam też zamieszkał po zakończeniu wojny polsko-bolszewickiej. W kwietniu 1921 roku przyjechał w odwiedziny do rodziny w Sosnowcu. Nawiązał kontakt z Komitetem Uchodźców Górnośląskich i wziął udział w trzecim powstaniu śląskim. Latem 1921 roku powrócił do Wilna, zdał maturę i wstąpił na Wydział Matematyczno-Przyrodniczy Uniwersytetu Stefana Batorego. Po ukończeniu studiów w 1924 wyjechał do Katowic, gdzie pracował w redakcji „Gazety Robotniczej" (jego żona Natalia pochodziła z Będzina). Równocześnie w latach 1927-1929 studiował w Wyższej Szkole Dziennikarskiej w Warszawie. Następnie pracował w „Głosie Trybunalskim” oraz w „Kurierze Lódzkim”. W 1928 roku wstąpił do Polskiej Partii Socjalistycznej, ale działalnością polityczną się nie zajmował. Na początku lat 30. rozstał się z żoną i wrócił na wieś do rodzinnego Galowa, gdzie przez kilka lat pracował wraz z matką na gospodarstwie rolnym.

W okresie dwudziestolecia międzywojennego jego głównym zajęciem była praca dziennikarska i literacka. Czekalski współpracował z prasą katolicką („Tęcza”, „Mały Dziennik”), pismami o orientacji chadeckiej („Polonia”) czy socjalistycznej („Expres Zagłębia”). W lipcu 1935 roku napisał krytyczny artykuł o obozie odosobnienia w Berezie Kartuskiej dla czeskiego pisma „Lidove Noviny”. Policja skonfiskowała artykuł jeszcze na poczcie w Busku Zdroju, a Czekalski został aresztowany. W grudniu 1935 roku Sąd Okręgowy w Kielcach skazał go na półtora roku więzienia za rozpowszechnianie poza granicami kraju wiadomości nieprawdziwych w celu szkodzenia interesom państwa. W marcu następnego roku Sąd Apelacyjny w Krakowie wydał wyrok uniewinniający i po dziewięciu miesiącach autor demaskatorskiego artykułu opuścił więzienie w Pińczowie.

Czekalski był bardzo płodnym autorem powieści o tematyce historycznej, romansów i książek sensacyjno-przygodowych. Napisał około 20 powieści, z których większość ukazała się w drugiej połowie lat 30. Jako literat zadebiutował w 1929 roku romansem historycznym Gdy królowa kocha: powieść o Barbarze Radziwittównie. Ta najbardziej popularna powieść Czekalskiego doczekała się przekładu czeskiego (1930), a po latach również litewskiego (1999). Akcja jego powieści sensacyjno-przygodowych toczy się często w egzotycznych miejscach: Syn potudnia (Maroko), Znajoma z ekspresu i Narzeczona z Szanghaju (Chiny), Kwiat szczęścia (Indonezja), Rekordy (USA), Pod rozpalonym niebem Argentyny, Skarb wielkiego Mogoła (Indie). W 1937 roku opublikował powieści Dżungla i Łuny nad Hiszpania, których akcja rozgrywa się w okresie rządów Frontu Narodowego i wojny domowej. W końcu lat 30. Czekalski pogodził się z żoną i ponownie zamieszkał w Katowicach. Pracował wówczas w redakcji „Polonii”.

Po wybuchu drugiej wojny światowej Czekalscy wyjechali na Kielecczyznę. Mieszkali w Kazimierzy Wielkiej, gdzie Adam zajmował się drobnym handlem. Zaangażował się również działalność konspiracyjną, początkowo w Polskiej Organizacji Zbrojnej, a następnie w Armii Krajowej (kolportował konspiracyjne gazetki). Już na początku lutego 1945 roku Czekalski przybył do Katowic, gdzie został kierownikiem Miejskiego Urzędu Informacji i Propagandy. Rok później Krajowa Rada Narodowa odznaczyła go srebrnym Krzyżem Zasługi. Niebawem został jednak oskarżony o nadużycia gospodarcze (sprawa została umorzona na mocy amnestii) i w marcu 1946 roku wyjechał na Dolny Śląsk, a w czerwcu do Szczecina, gdzie przez blisko rok (do kwietnia 1947) był drugim sekretarzem Wojewódzkiego Komitetu PPS ${ }^{8}$.

\footnotetext{
${ }^{8}$ Biogram A. Czekalskiego zob.: Z. Gębołyś, Czekalski Adam, [w:] Materiały do księgi życiorysów ludzi kultury literackiej Zagłębia Dąbrowskiego, pod red. A. W. Jarosza, cz. 3, Katowice 1994, s. 43-48; Archiwum Akt Nowych, Akta personalne Adama Czekalskiego, sygn. 14653;
} 
W 1946 i 1947 roku Wojewódzki Urząd Bezpieczeństwa Publicznego w Szczecinie odnotował szereg ,antypaństwowych” wypowiedzi Czekalskiego. Informatorzy „bezpieki" donosili o jego wrogości do PPR i UB. W prywatnych rozmowach Czekalski oskarżał PPR, że „bierze fundusze z ZSRR, czego nie robi PPS”. Ostrzegał: „albo PPS weźmie władzę w swoje ręce, albo będziemy musieli iść do lasu”. Twierdził, że „PPR dąży do monopartii, do dyktatury proletariatu na wzór radziecki, że UB działała na sposób sowiecki, aresztuje bez powodu. Temat o ZSRR doprowadza go do pasji”. W ocenie UB Czekalski prowadził „,skrytą działalność WRN-owską, mając na celu rozbicie jedności klasy robotniczej. [...] Reprezentuje kierunek zdecydowanie prawicowy o wrogim nastawieniu do Polskiej Partii Robotniczej i Zw[iązku] Radzieckiego"9.

W połowie lipca 1946 roku Czekalski informował Centralny Komitet Wykonawczy PPS o negatywnych skutkach nieproporcjonalnie wysokiej liczby wojsk sowieckich na terenie Pomorza Zachodniego: „Nadmierna ilość tych wojsk powoduje równocześnie i nadmierną ilość band maruderskich". Podając przykłady rabunków i napadów na polskie gospodarstwa przez „maruderów radzieckich” apelował do kierownictwa PPS „o poczynienie centralnych starań w tym kierunku, aby spowodować: a) odpływ znacznej części wojsk radzieckich i b) zakaz wywożenia mebli, okien, drzwi, a częstokroć nawet pieców kaflowych z mieszkań opuszczonych na Pomorzu Zachodnim, gdyż wywożenie tych rzeczy powoduje już dzisiaj ostry głód umeblowania i wręcz wrogie ustosunkowanie się ludności do Związku Radzieckiego"10.

Na początku września 1946 roku Czekalski alarmował kierownictwo PPS: „Stosunki na terenie Wojewódzkiej Komendy Milicji Obywatelskiej w Szczecinie przybrały już obecnie stan zapalny i dłużej w żadnym wypadku tolerowane być — przynajmniej — nie powinny”. Drugi sekretarz WK PPS w Szczecinie skarżył się, iż komendant wojewódzki MO major Sucharek z PPR ,tendencyjnie i rozmyślnie usuwa kolejno niemal wszystkich członków PPS, przy czym nie ukrywa bynajmniej głębokiej pogardy dla wszystkich PPSowców" ${ }^{\prime 1}$. W innym piśmie z listopada 1946 roku Czekalski informował władze PPS, iż „W ostatnim czasie wzrosło nasilenie terroru stosowanego przez PPR na terenie powiatów woj[ewództwa] szczecińskiego do naszych członków"12.

Po konflikcie z lokalnymi działaczami Czekalski w końcu kwietnia 1947 roku został usunięty ze stanowiska drugiego sekretarza WK PPS w Szczecinie, a niebawem wykluczono go również z szeregów PPS. Kierownictwo szczecińskiej organizacji PPS zarzucało mu popełnienie przestępstw „natury kryminalnej”. Czekalski wrócił wówczas do Katowic, gdzie pracował w wydawnictwie Książnica Śląska, jako redaktor działu młodzieżowego. Współpracował również z „Polską Zachodnią” czy katowicką „Odrą” oraz z Polskim Radiem we Wrocławiu i Szczecinie ${ }^{13}$.

AIPN, sygn. 0259/314, t. 1, k. 11-11A, A. Czekalski, Życiorys [28 VI 1946]; tamże, k. 110 110A, A. Czekalski, Życiorys [wrzesień 1947]; AIPN, sygn. 0259/314, t. 2, k. 17-22, Protokoły przesłuchania podejrzanego A. Czekalskiego z 4 i 5 VII 1948. Różne dokumenty dotyczące A. Czekalskiego z lat 1946-1949 zob.: AIPN, sygn. 0259/314, t. 1-2. Zob. też: I. Polit, Miejsce odosobnienia w Berezie Kartuskiej w latach 1934-1939, Toruń 2003, s. 50.

9 AIPN, sygn. 0259/314, t. 1, k. 5-7, Arkusz informacyjny „dossier” na przestępców przeciw Państwu WUBP w Szczecinie.

${ }^{10}$ Tamże, k. 85-86, Pismo A. Czekalskiego z 16 VII 1946 do CKW PPS.

${ }^{11}$ Tamże, k. 92, Pismo A. Czekalskiego z 6 IX 1946 do CKW PPS.

12 Tamże, k. 116, Pismo A. Czekalskiego z 19 XI 1946 do CKW PPS.

${ }^{13}$ Tamże, k. 110A, A. Czekalski, Życiorys [wrzesień 1947]; AIPN, sygn. 0259/314, t. 2, k. 19A, Protokół przesłuchania podejrzanego A. Czekalskiego z 5 VII 1948; Komunikat WK PPS Szczecin, Robotnik 1947 nr 151, s. 3. 
W listopadzie 1947 roku Czekalski nawiązał współpracę z wydawanym w Lens dziennikiem „Narodowiec” (z pismem redagowanym przez Michała Kwiatkowskiego współpracował jeszcze w latach 30.). Swoje korespondencje z Polski, drukowane przeważnie na pierwszej stronie, podpisywał pseudonimem Jan Karol Zambrowski. Pierwszy, po latach przerwy, artykuł Czekalskiego w „Narodowcu” ukazał się w numerze z 18 listopada 1947 roku. Komentując sytuację w kraju po wyjeździe prezesa Polskiego Stronnictwa Ludowego, Stanisława Mikołajczyka, podkreślił, że już po styczniowych „wyborach” sejmowych z 1947 roku:

Polska przestała być krajem nawet prymitywnej wolności, stała się zaprzeczeniem wszelkiego pojęcia demokracji, natomiast jest bezapelacyjną tubą obcej woli, która nie może znosić innej myśli, poza... nazwijmy to oględnie - myślą pepeerowską ${ }^{14}$.

W kolejnych artykułach wykpiwał rzekomy pluralizm polityczny w kraju, gdzie formalnie istniało sześć partii politycznych, ale w rzeczywistości tylko jedna, komunistyczna partia, „rządzi wszystkim, decyduje o wszystkim i wszystkiemu nadaje ton”. Pozostałe ugrupowania (PSL, SL, SP, SD) „to tylko wydziały PPR”, zaś partia socjalistyczna „nie ma absolutnie nic wspólnego z dawnymi ideałami PPS "15.

Występując przeciw fałszowaniu historii przez komunistów, którzy kreowali się na główną siłę walczącą podczas okupacji z Niemcami, Czekalski podkreślił:

Najwybitniejszą cechą życia politycznego w t.zw. „demokracjach ludowych”, uznających jedynie „wschodni system” — jest zakłamanie. Nigdy dotąd w Polsce nie byliśmy świadkami takiej nawały kłamstwa w życiu publicznym jak to widzimy dzisiaj i.. chcąc nie chcąc - uczestniczymy w nim. [...] I tak jest wszędzie! Kłamstwo jest zaprawą budowlaną tej nieszczęsnej „demokracji” dzisiejszej, na kłamstwie wszystko oparte — od najdrobniejszej rzeczy do najwznioślejszego aktu państwowego ${ }^{16}$.

Mimo takiej konstatacji Czekalski nie pogrążył się w pesymizmie: „dzieje uczą twierdził z nadzieją - że nic, cokolwiek na kłamstwie oparte - nie trwa długo. Nie może tedy utrzymać się i ustrój w Polsce, oparty na kłamstwie" ${ }^{\text {17. }}$.

Korespondent „Narodowca” piętnował narastającą totalizację życia politycznego, społecznego i gospodarczego w kraju. W jednym z artykułów stwierdził:

W Polsce nie ma ani wolności sumienia, ani wolności słowa, ani wolności organizacyj.

Jest tylko brutalna przemoc władzy paczki uzurpatorów z łaski Rosji sowieckiej ${ }^{18}$.

Już po kilku miesiącach współpracy z „Narodowcem” Czekalski został zdemaskowany przez „bezpiekę”. 21 maja 1948 roku Wydział II Wojewódzkiego Urzędu Bezpieczeństwa Publicznego w Warszawie zatrzymał list adresowany do mieszkającego w Lens Jana Fojcika. Anonimowa przesyłka zawierała trzy artykuły o „charakterze prowokacyjnym” podpisane Jan Karol Zambrowski. Na polecenie centrali terenowe wydziały UB miały zebrać szczegółowe informacje na temat nadawcy listu. W połowie czerwca Wydział II PUBP w Katowicach zatrzymał anonimową przesyłkę adresowaną do Jana Kuciaka zamieszkałego na wsi w okolicy Chełmży. Przesyłka składała się

${ }^{14}$ [A. Czekalski] J. K. Zambrowski, W Kraju po wyjeździe Mikołajczyka. Wycechowe panowanie w próżni chłopskiej, Narodowiec $1947 \mathrm{nr} 272$, s. 1.

${ }^{15}$ Tenże, W Polsce rządzi PPR, chociaż jest sześć ,,różnych” partyj, Narodowiec $1947 \mathrm{nr}$ 290 i 291 , s. 1.

${ }^{16}$ Tenże, Tragiczne zaktamanie, Narodowiec 1947 nr 307, s. 1.

${ }^{17}$ Tamże.

${ }^{18}$ [A. Czekalski] J. K. Zambrowski, Wolność słowa w Polsce, Narodowiec 1948 nr 94, s. 1. 
z dwóch dokumentów: listu o treści prywatnej, w którym nadawca (z treści wynikało, że był nim Adam Czekalski) prosił o wysłanie załączonego drugiego listu na adres zamieszkałego w Paryżu M. Maluty (po sprawdzeniu jego zawartości okazało się, że list zawierał artykuł „Zambrowskiego”). Już w lutym 1948 roku WUBP w Katowicach zatrzymał list adresowany do Fojcika z artykułami „Zambrowskiego” (nadawcą listu była Zofia Fojcik z Bytomia). Listy, które znalazły się w posiadaniu UB wskazywały, że to Czekalski przesyłał do Francji „prowokacyjne” artykuły używając do tego celu osoby trzecie. „Bezpieka” podejrzewała również, że może być ich autorem. Obserwacja potwierdziła te przypuszczenia. W końcu czerwca funkcjonariusze WUBP w Katowicach wyjęli ze skrzynki pocztowej list wrzucony przez Czekalskiego adresowany do Fojcika. Jak się okazało przesyłka zawierała kolejne artykuły „Zambrowskiego" ${ }^{, 19}$.

Jako podejrzany „o kontakty z zagranicą” Czekalski 3 lipca 1948 roku został aresztowany przez funkcjonariuszy WUBP w Katowicach. W jego mieszkaniu przeprowadzono rewizję, podczas której śledczy znaleźli kolejne dowody „przestępstwa”: kopertę z adresem wydawcy i redaktora „Narodowca” Michała Kwiatkowskiego oraz dwie koperty przygotowane do wysłania na adres Fojcika wraz z sześcioma artykułami „Zambrowskiego". Zarekwirowano również maszynę do pisania ${ }^{20}$.

Po zatrzymaniu podejrzany został przewieziony do Warszawy i osadzony w więzieniu na Mokotowie. Już nazajutrz po raz pierwszy przesłuchiwał go oficer śledczy MBP kapitan Jan Onacik. Przesłuchania kontynuowano w następnych dniach (5, 6 i 7 lipca). Czekalski przyznał się, że wysłał pocztą około 20 korespondencji do „Narodowca". Artykuły podpisywał pseudonimem Jan Karol Zambrowski. Oficer śledczy zarzucił mu, że wysyłając „materiały oszczercze wobec Państwa Polskiego” działał „przeciwko ustrojowi demokratycznemu w Polsce na korzyść międzynarodowej reakcji”". Czekalski swoje zachowanie tłumaczył osobistymi porachunkami i zemstą za krzywdy, jakie spotkały go ze strony PPS. Korespondent „Narodowca” w trakcie przesłuchań kluczył i wielokrotnie zasłaniał się brakiem pamięci. Twierdził np., że zaczął współpracować z „Narodowcem” wiosną, a może w lutym czy nawet w styczniu 1948 roku. Zapewniał też, że przy wysyłaniu korespondencji do Francji nie korzystał z niczyjego pośrednictwa ${ }^{21}$.

Niebawem sprawę Czekalskiego przejął do prowadzenia młodszy oficer śledczy MBP Aleksy Wszołek. W końcu września 1948 roku rozpatrzywszy materiały dochodzenia wszczął też formalnie śledztwo przeciwko Czekalskiemu ${ }^{22}$.

W materiałach dotyczących korespondenta „Narodowca” zachowały się jeszcze dwa protokoły przesłuchan z 19 i 30 października 1948 roku. Wszołek wypytywał go o przedwojenną działalność polityczną i publicystyczną. Interesował się również tym, kto z jego znajomych po wojnie wysyłał artykuły do „Narodowca”. Czekalski podkre-

${ }^{19}$ AIPN, sygn. 0259/314, t. 2, k. 4-4A, Raport z 24 VI 1948 dot. sprawy Jana Karola Zambrowskiego; tamże, k. 7-8, Plan rozpracowania oraz realizacji obiektu „J. K. Zambrowski” oraz jego kontaktów.

${ }^{20}$ Tamże, k. 12, Nakaz zatrzymania A. Czekalskiego z 3 VII 1948; tamże, k. 13, Postanowienie o zarządzeniu rewizji domowej u A. Czekalskiego z 3 VII 1948; tamże, k. 24, Protokół przesłuchania podejrzanego A. Czekalskiego z 5 VII 1948.

${ }^{21}$ Tamże, k. 24-25, Protokół przesłuchania podejrzanego A. Czekalskiego z 5 VII 1948; tamże, k. 23-31, Protokoły przesłuchań podejrzanego A. Czekalskiego z 5, 6 i 7 VII 1948.

${ }^{22}$ Tamże, k. 16, Postanowienie o wszczęciu śledztwa przeciwko A. Czekalskiemu z 30 IX 1948. 
ślił, że współpracę z „Narodowcem” nawiązał sam, już w październiku 1947 roku, i z nikim na ten temat nie rozmawiat ${ }^{23}$.

Do czasu aresztowania Czekalskiego na łamach „Narodowca” ukazało się ogółem 37 artykułów sygnowanych przez „Jana Karola Zambrowskiego”. Do końca 1948 roku w „Narodowcu” ukazało się jeszcze 16 kolejnych korespondencji z kraju podpisanych pseudonimem używanym przez Czekalskiego (ostatnia w numerze z 17 grudnia). Tematyka oraz styl artykułów wskazuje, że ich autorem był zapewne Czekalski. Niektóre z tekstów (dla kamuflażu?) podlegały uwspółcześniającym je przeróbkom redakcyjnym. Prawdopodobnie około 20 artykułów zostało zatrzymanych przez „bezpiekę” i nie dotarło do redakcji „Narodowca”.

29 marca 1949 roku prokurator T. Majewski sporządził akt oskarżenia i przesłał go do Sądu Okręgowego w Warszawie. Czekalski został oskarżony o to, że:

\begin{abstract}
w czasie od października 1947 r. do końca czerwca 1948 r. na obszarze Polski, sporządził ponad 70 artykułów, opisujących fałszywie stosunki panujące w Polsce Ludowej oraz wyszydzających Sejm, Rząd i inne władze państwowe, a następnie artykuły te przesyłał do redakcji wychodzącego we Francji w języku polskim dziennika „Narodowiec”, gdzie były one zamieszczane na pierwszej stronie, w wyniku czego, przez rozpowszechnienie zawartych $\mathrm{w}$ artykułach fałszywych wiadomości wyrządził Państwu Polskiemu wielką szkodę, polegającą na wprowadzaniu w błąd Polaków przebywających we Francji odnośnie stosunków panujących w Polsce Ludowej.
\end{abstract}

W uzasadnieniu prokurator stwierdził, iż „Polacy znajdujący się na całym świecie powinni znać prawdę o Nowej Polsce, prawdę o osiągnięciach i sukcesach Polski w dziedzinie gospodarczej oraz o tym, że w Polsce po raz pierwszy w jej historii realizowany jest ustrój oparty na równości i sprawiedliwości społecznej, mający na celu dobro ludu pracującego”. W ocenie prokuratora w działalności dziennikarskiej Czekalskiego „od dawna istniały elementy antydemokratyczne i sympatia dla faszyzmu”. Świadczyć miała o tym w szczególności jego książka Łuny nad Hiszpanią (Łomża 1937), ,pochwalająca faszystowski zamach generała Franco"24.

Za te ,przestępstwa” Sąd Okręgowy w Warszawie 27 kwietnia 1949 roku skazał korespondenta „Narodowca” na dożywocie. Sędzia E. Osmólski w sentencji wyroku podkreślił, iż Czekalski „należy do typu szczególnie niebezpiecznych przestępców wobec Państwa”, a „charakter konspiracyjnej i bezwzględnej walki, jaką oskarżony prowadził z Polską Ludową wymaga zupełnej eliminacji oskarżonego w postaci dożywotniego więzienia”. Przeciwko Czekalskiemu przemawiała nawet jego „dodatnia przeszłość" (udział w trzecim powstaniu śląskim, walka piórem z sanacją, Krzyż Partyzancki). W ocenie sądu oskarżony, właśnie ze względu na swą przeszłość, ,powinien był pozytywnie ustosunkować się do nowej rzeczywistości w Polsce”, jednak „czyny jego zadały temu kłam, przekreślając zarazem te zasługi" 25 . Nawet jak na standardy komunistycznych sądów wyrok był niewspółmierny do popełnionego czynu.

Groźnego przestępcę napiętnowano również na łamach prasy. „Express Wieczorny” w notatce o procesie „sanacyjnego” współpracownika „faszystowskiego” dziennika w Lens napisał: „Czekalski, mieszkając w Katowicach, preparował tam zatrute jadem fałszu artykuły, opisujące w czarnych barwach stosunki w kraju, wyszydzające Sejm,

23 Tamże, k. 32-35, Protokoły przesłuchań podejrzanego A. Czekalskiego z 19 i 30 X 1948.

24 Tamże, k. 37-39, Akt oskarżenia przeciwko A. Czekalskiemu z 29 III 1949.

25 AIPN By., sygn. 112/1057, k. 7-9, Sentencja wyroku przeciwko A. Czekalskiemu z 27 IV 1949. 
Rząd i inne władze państwowe”. Na szczęście „władze bezpieczeństwa zlikwidowały krecią robotę Czekalskiego"26.

Ostatecznie Sąd Apelacyjny 28 lipca 1950 roku zmniejszył wyrok przeciwko korespondentowi „Narodowca” do ośmiu lat. Skazany odsiadywał karę w więzieniu na Mokotowie w Warszawie, a później we Wronkach. Na mocy amnestii wyrok złagodzono do pięciu lat i czterech miesięcy. Z więzienia został zwolniony 14 listopada $1953 \mathrm{roku}^{27}$.

Po wyjściu na wolność Czekalski wrócił do Katowic (Stalinogrodu), gdzie mieszkał przed aresztowaniem. Jednak gdy odsiadywał wyrok do jego mieszkania w czerwcu 1951 roku wprowadził się nowy lokator. Prezydium Miejskiej Rady Narodowej w Katowicach uznało, że trzypokojowe mieszkanie Czekalskich nie było „odpowiednio zagęszczone" i przyznało dwa pokoje z kuchnią na prawach współnajemcy Leonowi Broniewiczowi. Nowego lokatora popierał Komitet Miejski PZPR w Katowicach. Żonie Czekalskiego pozostawiono jeden pokój z prawem używania kuchni. Broniewicz chcąc ją zmusić do tego, aby wyprowadziła się z mieszkania oskarżył ją o słuchanie wrogich Polsce Ludowej zagranicznych „szczekaczek radiowych” (Radia Wolna Europa). Na tej podstawie UB w maju 1953 roku aresztowało Czekalską. Musiano ją jednak zwolnić po czterech dniach, gdyż jak się okazało Czekalska w ogóle nie miała radioodbiornika. Gdy to nie poskutkowało Broniewicz samowolnie zmienił zamek w drzwiach wejściowych i nie wydał Czekalskiej nowych kluczy. W rezultacie przez cztery miesiące nie mogła się ona dostać do własnego mieszkania. Gdy Czekalski wyszedł z więzienia nieproszony lokator nadal nie zamierzał opuścić mieszkania. Oskarżył nawet Czekalskich o szereg „chuligańskich wybryków”. Nie pomogły ich skargi do Komitetu Miejskiego i Wojewódzkiego PZPR w Stalinogrodzie. Czekalscy byli bezsilni. Nie mogli się pozbyć niechcianego ,gościa”, a władze tolerowały to bezprawie ${ }^{28}$.

Na początku września 1954 roku Czekalscy przenieśli się do Torunia, gdzie zamieszkali na terenie ogródków działkowych. Czekalski sam wyremontował trzypokojowy domek, który był własnością jego kuzyna: wstawił nowe okna i piece, wymienił podłogę. Jako były więzień długo nie mógł jednak dostać żadnej stałej pracy. Utrzymywał się z paczek nadsyłanych mu przez znajomych z Wielkiej Brytanii, Stanów Zjednoczonych i Czechosłowacji. Dorywczo zajmował się thumaczeniem książek na język polski. Pisał też nowele i powieści. Dopiero wiosną 1955 roku został zatrudniony w Robotniczej Spółdzielni Odzieżowej w Chełmży na stanowisku referenta gospodarczego ${ }^{29}$.

Byłym więźniem nie przestała się natomiast interesować „bezpieka”. Na podstawie donosów agenturalnych ustalono, że w rozmowach prywatnych Czekalski „dość często wyraża się wrogo w stosunku do panującego ustroju — do Polskiej Rzeczypospolitej Ludowej i Związku Radzieckiego wykazuje stosunek wrogi. Jest gorliwym praktykiem [!] i popiera dogmaty religijne”. Informator „Wdały” donosił, że Czekalski pozytywnie wypowiadał się o swoim znajomym, który kształcił syna na księdza. Innym razem

\footnotetext{
${ }^{26}$ Sanacyjny dziennikarz przed sądem za szkalowanie Polski Ludowej w faszystowskim piśmie emigracyjnym, Express Wieczorny 1949 nr 115, s. 2; Z. Gębołyś, Czekalski Adam, s. 44.

${ }^{27}$ AIPN By., sygn. 044/288, t. 1, k. 25, Raport z 7 XII 1955 o wszczęciu rozpracowania agenturalnego na osobę pod krypt. „Literat”; tamże, k. 16, A. Czekalski, Życiorys z 7 IV 1955; Z. Gębołyś, Czekalski Adam, s. 44.

${ }^{28}$ Korespondencja w sprawie mieszkania zob.: AIPN By., sygn. 112/1057, k. 99-109.

${ }^{29}$ AIPN By., sygn. 070/4111, k. 24, Pismo naczelnika Wydziału VII WUds.BP w Bydgoszczy z 31 I 1956 do naczelnika wydziału VII WUds.BP w Stalinogrodzie. Zob. też: AIPN By., sygn. 044/288, t. 1, k. 118-121, 125, Wyciągi z doniesień agenturalnych informatorów „Waldy” i „Karp” z 13, 21 i 23 X oraz 2 XII 1954.
} 
Czekalski ostrzegał go, aby zachowywał ostrożność przy pisaniu listów, gdyż nie wszystkie przesyłki dochodzą do adresatów. Czekalski nie zrażał się tym, że jego tekstów nie chciało wydrukować żadne wydawnictwo. Twierdził, że pisze na przyszłość i wierzył, że sytuacja niebawem zmieni się na korzyść. W rozmowie z informatorem „Karp” narzekając na wysokie cło, jakie płacił za lekarstwa otrzymywane z zagranicy, Czekalski dodał, iż ,żyje ponieważ jest myśli, że ten gmach — jak się wyraził — obłudy i zła w końcu runie, ponieważ oparty jest na fundamentach nienawiści, a on nie mógłby żyć i nie warto byłoby mu żyć, gdyby nie pewny był zwycięstwa, ponieważ nie mógłby patrzeć na zwycięstwo zła. Lecz zło to jest nietrwałe, gdyż w końcu musi skapitulować przed dobrem i miłością”. „Karp” donosił również, że Czekalski prawdopodobnie słucha zagranicznego radia ${ }^{30}$.

Niebawem Czekalski ponownie znalazł się w poważnych tarapatach. 4 listopada 1955 roku Urząd Celny w Warszawie zatrzymał przesyłkę, wysłaną dwa dni wcześniej na poczcie w Chełmży na adres mieszkającej w Toledo w stanie Ohio (USA) Yvonne Bronowicz (formalnie nadawcą listu była Anna Bronowicz z pobliskiego Głuchowa). Jak się okazało podejrzana przesyłka zawierała pamiętnik z roku 1945 zatytułowany „Śladami Jałty” oraz wspomnienia z pobytu w więzieniu „A gdy nadejdzie dzień zapłaty”. Dla zmylenia czujności celników i funkcjonariuszy „bezpieki” maszynopis umieszczony był w okładkach książki Rycerze $i$ ciury Władysława Rymkiewicza. W następnych dniach zatrzymano również trzy prywatne listy Czekalskiego wysłane na adres Tadeusza Piskorskiego we Francji oraz list do Josepha Bronowicza mieszkającego w Stanach Zjednoczonych. O nadanie „wrogiej” przesyłki podejrzewano Czekalskiego. Kolejnym dowodem stała się koperta przechowywana w aktach archiwalnych sprawy Czekalskiego, skonfiskowana podczas rewizji w jego mieszkaniu w 1948 roku. Adresy na kopercie z 1948 roku oraz na tej, w której wysłana była „książka” do USA napisane były podobnym charakterem pisma. Podejrzenia potwierdziło badanie wykonane w Centralnym Laboratorium Ekspertyz. Porucznik Edmund Napierała z Wojewódzkiego Urzędu do Spraw Bezpieczeństwa Publicznego w Bydgoszczy rozpatrzywszy materiały dotyczące Czekalskiego przygotował 6 grudnia 1955 roku postanowienie o założeniu ,sprawy agenturalnej na osobę” o kryptonimie „Literat” (sprawa miała charakter „wrogiej propagandy pisanej”). Oficer „,bezpieki” stwierdził, że Czekalski „usiłował przesłać 43 strony maszynopisu o wrogiej treści, szkalującej ustrój PRL". Również kolejne listy Czekalskiego adresowane za granicę w listopadzie 1955 roku posiadały „wrogą” treść (nadawca żalił się na swoją trudną sytuację materialną). W konsekwencji inwigilacją objęte zostały wszystkie rodzaje przesyłek pocztowych na adresy przechodzące $\mathrm{w}$ sprawie $\mathrm{s}^{31}$.

14 grudnia 1955 roku oficer śledczy bydgoskiej „bezpieki”, chorąży S. Witkowski, formalnie wszczął śledztwo przeciwko Adamowi Czekalskiemu. Tego samego dnia porucznik Napierała przygotował wniosek o zastosowanie wobec podejrzanego aresztu tymczasowego oraz przeprowadzenie w jego domu rewizji. Oba wnioski w ekspresowym tempie podpisał prokurator M. Derkacz ${ }^{32}$.

${ }^{30}$ AIPN By., sygn. 044/288, t. 1, k. 40-41, Pismo kierownika PUBP w Toruniu z 3 II 1955. do naczelnika Wydziału III WUBP w Szczecinie. Zob. też: tamże, k. 118-121, 125, Wyciągi z doniesień agenturalnych informatorów „Waldy” i „Karp” z 13, 21 i 23 X oraz 2 XII 1954.

${ }^{31}$ Tamże, k. 9, Postanowienie z 6 XII 1955 o założeniu sprawy agenturalnej na osobę kryptonim „Literat”; tamże, k. 25-28,Raport z 7 XII 1955 o wszczęciu rozpracowania agenturalnego na osobę pod krypt. „Literat”.

32 AIPN By., sygn. 070/4111, k. 10-11, Postanowienie z 14 XII 1955 o wszczęciu śledztwa przeciwko A. Czekalskiemu; tamże, k. 12-13, Wniosek z 14 XII 1955 o aresztowanie A. Czekal- 
Już następnego dnia porucznik Grzegorz Leszkiewicz przeprowadził rewizję w mieszkaniu Czekalskiego. Podczas przeszukania funkcjonariusz zarekwirował dwie maszyny do pisania oraz kilka przedwojennych książek (w tym Łuny nad Hiszpania autorstwa Czekalskiego). Sam podejrzany został tymczasowo aresztowany. Z Torunia przewieziono go do więzienia karno-śledczego w Bydgoszczy, skąd w lutym 1956 roku trafił do szpitala więziennego w Grudziądzu ${ }^{33}$.

$\mathrm{Na}$ początku kwietnia 1956 roku Leszkiewicz przygotował akt oskarżenia przeciwko Czekalskiemu. Oficer śledczy powtórzył zarzuty postawione podejrzanemu w śledztwie. W uzasadnieniu dodał, że oskarżony już „w okresie międzywojennym należał do grupy pisarzy gloryfikujących w swych utworach faszyzm. W okresie tym obok pracy dziennikarskiej napisał on szereg publikacji profaszystowskich". Skonfiskowana podczas rewizji książka Czekalskiego Łuny nad Hiszpanią była „wyrafinowanym paszkwilem, skierowanym przeciwko ludowi hiszpańskiemu walczącemu o swą wolność przeciwko dyktaturze Franco" ${ }^{34}$.

Do ponownego procesu i niechybnego skazania Czekalskiego jednak nie doszło. Na mocy uchwalonej w końcu kwietnia 1956 roku amnestii Sąd Wojewódzki w Bydgoszczy 4 maja umorzył postępowanie ${ }^{35}$.

Choć Czekalski został zwolniony z aresztu śledczego nadal znajdował się pod obserwacją ,bezpieki”. 20 sierpnia 1956 roku podporucznik Wiesław Drążewski, oficer operacyjny Wydziału III Wojewódzkiego Urzędu do Spraw Bezpieczeństwa Publicznego w Bydgoszczy przygotował postanowienie o założeniu ,sprawy ewidencyjnoobserwacyjnej” na Adama Czekalskiego jako na osobę, która „stara się rozpowszechniać wrogą propagandę pisaną o PRL" ${ }^{\text {"36 }}$.

W końcu października sprawę Czekalskiego przekazano do dalszego prowadzenia przez Powiatowy Urząd do Spraw Bezpieczeństwa Publicznego w Toruniu. Ze względu na miejsce zamieszkania i pracy „figuranta” toruńska „bezpieka” miała „większe możliwości w agenturalnej obserwacji wymienionego" ${ }^{\$ 7}$. Formalnie podporucznik Marian Łowicki z Torunia 12 listopada 1956 roku przygotował postanowienie o założeniu sprawy ewidencyjno-obserwacyjnej na Czekalskiego. Oficer operacyjny za wskazane uznał dalsze prowadzenie rozpracowania „figuranta”, który „,nieustannie wykazuje wrogi stosunek do Polski Ludowej" ${ }^{38}$.

$\mathrm{Na}$ fali październikowej „odwilży” Czekalski ponownie nawiązał współpracę $\mathrm{z}$ „Narodowcem”. Mimo kilkuletniego pobytu w więzieniu i zrujnowanego zdrowia

skiego i przeprowadzenie rewizji; tamże, k. 14-15, Postanowienie o tymczasowym aresztowaniu z 14 XII 1955; tamże, k. 16, Postanowienie o zarządzeniu rewizji z 14 XII 1955.

${ }^{33}$ Tamże, k. 17, Protokół rewizji z 15 XII 1955; AIPN By., sygn. 044/288, t. 1, k. 29, Meldunek WUds.BP w Bydgoszczy z 16 XII 1955 do naczelnika Wydziału VI Departamentu III Kds.BP; AIPN By., sygn. 070/4111, k. 41, Pismo WUds.BP w Bydgoszczy z 17 III 1956 do naczelnika Centralnego Więzienia w Bydgoszczy.

${ }^{34}$ AIPN By., sygn. 070/4111, k. 51-56, Akt oskarżenia z 9 IV 1956 przeciwko A. Czekalskiemu.

${ }^{35}$ Tamże, k. 67, Postanowienie Sądu Wojewódzkiego w Bydgoszczy z 4 V 1956.

${ }^{36}$ AIPN By., sygn. 044/288, t. 1, k. 8, Postanowienie z 20 VIII 1956 o założeniu sprawy ewidencyjno-obserwacyjnej na A. Czekalskiego.

37 Tamże, k. 30, Postanowienie z 29 X 1956 o przekazaniu sprawy ewidencyjno-obserwacyjnej na A. Czekalskiego.

38 Tamże, k. 7, Postanowienie z 12 XI 1956 o założeniu sprawy ewidencyjno-obserwacyjnej na A. Czekalskiego; tamże, k. 10-11, Raport z 12 XI 1956 dot. analizy sprawy ewidencyjno-operacyjnej krypt. „Literat” i podjęcia wniosku, co do dalszego jej prowadzenia. 
nadal pozostał niezłomny duchem. Podobnie jak miliony Polaków miał też nadzieję, że Władysław Gomułka będzie najlepszym gwarantem demokratycznych przemian. Upatrywanie w nowym I sekretarzu KC PZPR przywódcy, który poprowadzi Polaków do niepodległości, demokracji i dobrobytu okazało się wielkim nieporozumieniem. Przekonał się o tym również Czekalski. Na razie jednak, w swoim pierwszym po kilkuletniej przerwie artykule na łamach „Narodowca” z 24 listopada 1956 roku, pisał z entuzjazmem i nadzieją:

Jednym z nie byle jakich dowodów wielkich przemian w Polsce dzisiaj jest między innymi choćby ten dość prosty i zrozumiały dla ludzi na Zachodzie fakt, że ja, Polak, obywatel Polski Ludowej, zamieszkały w jej granicach, mogę dzisiaj pisać do Was korespondencję o tym wszystkim, co się w Kraju dzieje, bez najmniejszych obaw oto, że po wydrukowaniu tego listu zjawią się przedstawiciele bezpieki, zabiorą mnie ze sobą i osadzą w kryminale.

Jeśli w minionym dziesięcioleciu (1946-1956) „kłamano, oszukiwano, terroryzowano naród, wtłaczano go w otchłań nędzy, upośledzenia i prywacji i kazano mu jeszcze wołać: «niech żyje» i «byczo jest!»”, to Gomułka wpuścił „strumień świeżego powietrza i prawdy o naszej rzeczywistości” oraz „zburzył gmach kłamstwa i fałszu”. Co znamienne, ten i kolejne artykuły Czekalski tym razem drukował pod własnym nazwiskiem $^{39}$.

Miesiąc później tłumaczył czytelnikom „Narodowca”:

Październikowy przełom w Polsce, to uśmiercenie zła wynikającego z siania nienawiści i narodzenie się nadziei. Nic się nie rodzi z nienawiści, natomiast wszystko rodzi się z miłości ${ }^{40}$.

Czekalski wytykał krajowym dziennikarzom i pisarzom konformizm, obłudę, strach oraz brak chęci rozliczenia się z przeszłością:

Ale czyż to asekuranctwo - pytał — nie jest równoznaczne $\mathrm{z}$ obroną hańby dni minionych? Kto milczy ten się zgadza. Czyli w naszym przypadku milczenie o straszliwych zbrodniach, zatajanie ich rozmyślne, tendencyjne i w obawie o własną skórę, która może być zagrożona, gdyby stalińczycy znowu wzięli górę - to wszystko jest obroną hańby i określa charakter człowieka - bardzo marny charakter i bardzo marnego człowieka ${ }^{41}$.

Innym razem bronił polityki Gomułki przed atakami emigracji:

$\mathrm{Ci}$, którzy na emigracji twierdzą, że „należy atakować Gomułkę dlatego, że jest on komunista i rządy przez niego ustalone opierają się na komunizmie" - zdradzają całkowitą ignorancję, co do tego, co się w Kraju do dnia 19 października [1956 roku] działo ${ }^{42}$.

Z nadzieją pisał też o wynikach wyborów do sejmu PRL z 20 stycznia 1957 roku:

głosowaliśmy w Kraju nie na osoby, a więc nie na [Józefa] Cyrankiewicza, [Romana] Zambrowskiego, ale na program odrodzenia Rzeczypospolitej. Niedzielne wybory były zwycięstwem odnowy i naprawy Rzeczypospolitej. Lecz zwycięstwo polityczne to jeszcze nie wszystko!

Naród czekała odbudowa zrujnowanej gospodarki (,,bitwa gospodarcza”43.

\footnotetext{
${ }^{39}$ A. Czekalski, Na gruzach kłamstwa, Narodowiec 1956 nr 278, s. 1.

${ }^{40}$ Tenże, Nadzieja zastępuje nienawiść, Narodowiec $1956 \mathrm{nr} 301$, s. 3.

${ }^{41}$ Tenże, Obrońcy hańby, „Narodowiec” 1956, nr 306, s. 1, 3.

${ }^{42}$ Tenże, Suwerenność i położenie geograficzne, Narodowiec $1957 \mathrm{nr}$ 9, s. 1, 3.

${ }^{43}$ Tenże, Innego wyjścia nie było, Narodowiec 1957 nr 27, s. 1.
} 
W tym samym czasie Służba Bezpieczeństwa ponownie natrafiła na ślad „,przestępczej” działalności Czekalskiego. Dyrektor Departamentu III Ministerstwa Spraw Wewnętrznych pułkownik Zbigniew Paszkowski 17 stycznia 1957 roku przesłał bydgoskiej „bezpiece” fotokopie dwóch listów Czekalskiego do redakcji „Narodowca”. W związku z przejęciem „wrogiej” korespondencji oficer z centrali polecił założyć przeciwko Czekalskiemu „sprawę agenturalno-śledczą” i zażądać w prokuraturze „formalnego aresztu na korespondencję,"44.

Pętla wokół Czekalskiego zaciskała się coraz bardziej. Kilka dni później zastępca komendanta wojewódzkiego MO do Spraw Bezpieczeństwa Publicznego w Bydgoszczy podpułkownik Jan Onacik zwrócił się do Prokuratury Wojewódzkiej o wydanie postanowienia zajęcia korespondencji wychodzącej od Czekalskiego i przychodzącej do niego. W uzasadnieniu wniosku funkcjonariusz stwierdził, iż Czekalski:

systematycznie wysyła do redakcji dziennika wychodzącego we Francji pn. „Narodowiec" artykuły przedstawiające fałszywie i w niewłaściwym świetle stosunki panujące obecnie w Polsce.

Dodał, iż za podobną działalność był on już wcześniej dwukrotnie aresztowany. Jeszcze tego samego dnia wiceprokurator wojewódzki Marcinkowski wydał postanowienie o zajęciu na okres trzech miesięcy korespondencji Czekalskiego ${ }^{45}$.

Służba Bezpieczeństwa zablokowała również Czekalskiemu możliwość wyjazdu za granicę. Korespondent „Narodowca” zamierzał wyjechać do Francji „w odwiedziny do przyjaciół i dla leczenia”. Przebywać miał u „brata ciotecznego” Tadeusza Piskorskiego zamieszkałego w Hénin-Liétard w pobliżu Lens (za pośrednictwem Piskorskiego Czekalski przekazywał artykuły do „Narodowca”). W pierwszych dniach lutego 1957 roku podpułkownik Onacik przesyłając kwestionariusz paszportowy Czekalskiego zawiadomił dyrektora Biura Ewidencji Operacyjnej MSW, że bydgoska SB prowadzi przeciwko niemu ,aktywne rozpracowanie”. W tej sytuacji — podkreślił — Czekalskiemu „nie należy w żadnym wypadku udzielić zezwolenia na wyjazd za granicę"46.

Zgodnie z wytycznymi 13 lutego 1957 roku kapitan Stanisław Trzebuniak, oficer operacyjny Referatu III Powiatowego Urzędu do Spraw Bezpieczeństwa Publicznego w Toruniu, rozpatrzywszy materiały dotyczące Adama Czekalskiego przygotował postanowienie o założeniu „sprawy agenturalnej na osobę” o zabarwieniu „wroga propaganda - pisana” i nadał jej kryptonim „Redaktor”. Na podstawie perlustracji korespondencji Biuro „W” (pion kontroli korespondencji SB) ustaliło, iż „W ostatnim okresie” Czekalski wysłał do redakcji „Narodowca” na adres T. Piskorskiego 42 listy „o treści dotyczącej życia gospodarczego i politycznego naszego kraju, w których szkaluje ustrój Polski Ludowej”. Do SB dotarły ponadto informacje, że „figurant” próbował również nawiązać kontakt z pracownikami Zakładów Przemysłu Metalowego imienia Hipolita Cegielskiego w Poznaniu. Rzekomo na polecenie nieustalonych osób za-

${ }^{44}$ AIPN By., sygn. 044/288, t. 2, k. 167, Pismo Z. Paszkowskiego z 17 I 1957 do naczelnika Wydziału III WUds.BP w Bydgoszczy.

45 Tamże, k. 170, Pismo J. Onacika z 26 I 1957 do Prokuratury Wojewódzkiej w Bydgoszczy; AIPN By., sygn. 044/288, t. 3, k. 8, Postanowienie z 26 I 1957 o zajęciu korespondencji A. Czekalskiego.

${ }^{46}$ AIPN By., sygn. 070/4111, k. 195, Pismo J. Onacika z 5 II 1957 do dyrektora Biura Ewidencji Operacyjnej MSW; tamże, k. 192, Kwestionariusz paszportowy A. Czekalskiego z 20 XII 1956. 
mieszkałych na terenie Francji zamierzał przekazać pomoc materialną poszkodowanym podczas poznańskiego Czerwca ${ }^{47}$.

Korespondent „Narodowca” podejrzewał, że jego listy mogą być czytane przez niepowołane osoby. 18 stycznia 1957 roku Czekalski wysłał ,prowokacyjny” list do ministra łączności z pytaniem „,czy w Polsce w dalszym ciągu jest praktykowane kontrolowanie i zatrzymywanie listów wysyłanych zagranicę, jak za najlepszych czasów stalinowskich, czy też, zgodnie z Konstytucją i zarządzeniami listy te są wolne od tych praktyk". Dopytywał się, dlaczego listy lotnicze do Francji idą blisko miesiąc, albo w ogóle nie docierają do adresata.

Ponieważ odnowa życia polskiego — pisał Czekalski — nastąpiła również i w tej dziedzinie, przeto jest dla mnie zagadką, dlaczego tego rodzaju praktyki dziać się mogą nadal. Wyjaśnieniem może tu być jedyne przypuszczenie, że „czarne gabinety” pocztowe nadal istnieją i zatrzymują listy nie zawierające żadnych materiałów szpiegowskich czy czegoś podobnego, a wędrówka listu lotniczego w ciągu 24-30 dni wynika zapewne z tej przyczyny, o ile nie z prostego niedbalstwa. [...] Wszystko to nie świadczy dobrze o sprawności polskiej poczty, która przecież przed wojną chlubiła się jedną z najlepszych marek w Europie ${ }^{48}$.

Dociekliwość „figuranta” i porównanie z „sanacyjną” pocztą musiały zirytować funkcjonariuszy SB, do których dotarła skarga Czekalskiego do ministra łączności.

W końcu lutego 1957 roku Czekalski napisał również list do redakcji „Expressu Wieczornego", w którym prostował fałszywe oskarżenia pod swoim adresem sprzed kilku lat. W 1949 roku popularna popołudniówka zamieściła notatkę o procesie „,sanacyjnego dziennikarza” (chodziło o Czekalskiego) ,za szkalowanie Polski Ludowej w faszystowskim piśmie emigracyjnym” (to o „Narodowcu”). W zakończeniu listu Czekalski podkreślił, że zawsze występował „przeciwko tyranii, gwałtowi i terrorowi wszelkich reżimów i wszelkich bezpiek i ich pochodnych, jako systemu wrogiego wolności, suwerenności państwowej i narodowej i humanizmowi socjalistycznemu. Bo jestem wrogiem wszelkich rządów przy pomocy bata i dlatego nawet w okresie najwyższej wszechwładzy i rozkwitu zbrodni bezpieki w Polsce - protestowałem przeciwko temu publicznie, ${ }^{\text {,49 }}$. List został przejęty przez SB i prawdopodobnie nigdy nie dotarł do redakcji „Expressu Wieczornego”.

W sprawie Czekalskiego nie wszystko szło jednak po myśli funkcjonariuszy SB. Podpułkownik Onacik żalił się kierownictwu MSW, że według bydgoskiej prokuratury listy krajowego korespondenta „Narodowca” nie zawierały cech przestępstwa. A przecież — alarmował Onacik — w przypadku Czekalskiego chodziło o ,sprawę zasadniczą":

Czy obywatel PRL — pytał esbek — może pozostawać płatnym współpracownikiem reakcyjnego dziennika emigracyjnego, który chociaż jest dziennikiem prywatnym jest on jednak jednocześnie organem Mikołajczyka na emigracji, uznanego u nas jako wroga narodu polskiego.

Zaniepokojony oficer SB pisał do centrali:

Jeśli zdaniem Prokuratury nie jest to wroga działalność, to w takim razie każdy obywa-

${ }^{47}$ AIPN By., sygn. 044/288, t. 2, k. 7, Postanowienie z 13 II 1957 o założeniu sprawy agenturalnej na osobę kryptonim „Redaktor”; tamże, k. 11-14, Raport z 19 II 1957 o zatwierdzenie założenia sprawy agenturalnej na osobę krypt. „Redaktor” nr rejestracyjny 36/57.

${ }^{48}$ Tamże, k. 57, Pismo A. Czekalskiego z 18 I 1957 do ministra łączności.

49 AIPN By., sygn. 044/288, t. 1, k. 250-251, List A. Czekalskiego z 25 II 1957 do redakcji „Expressu Wieczornego”. 
tel w kraju miałby prawo stać się korespondentem takich szmatławców emigracyjnych jak: „Dziennik Polski i Dziennik Żołnierza”, „Orzeł Biały”, „Jutro Polski” itd.

Jeszcze „bardziej przykre” było to, że mieszkający we Francji Polak, niejaki Stanisław Czarka „trzeźwiej ocenia tę sytuację, bardziej po obywatelsku niż nasza Prokuratura”. Podpułkownik Onacik dodał, iż Czekalski „,rozwydrzony bezkarnością w bezczelny sposób zwraca się z pretensjami do «Życia Warszawy» oraz do Ministra Łączności" z pytaniem dlaczego nie wszystkie jego listy wysyłane do Francji dochodzą do adresatów. Wystąpił również do Biura Paszportów Zagranicznych o wydanie paszportu na wyjazd do Francji ${ }^{50}$.

Po interwencji Onacika sprawie Czekalskiego przyjrzała się centrala MSW. W „Notatce służbowej” z 21 marca A. Czerniak stwierdził, iż treść artykułów Czekalskiego w „Narodowcu” podpisanych jego nazwiskiem i imieniem:

w przeważającej większości stanowią negatywne strony życia naszego kraju. Artykuły te pisane są w formie napastliwej i zjadliwej. Trzeba zaznaczyć, że najczęściej ostrzem swoim uderzają one w stosunki polityczne i gospodarcze jakie panowały u nas do października. Tematem do wszystkich artykułów pisanych przez Czekalskiego są wiadomości, które podawała prasa krajowa. Dlatego też w artykułach Czekalskiego jest cała masa cytatów z prasy krajowej wraz z ostrożnymi choć jednak ostrymi komentarzami autora. Oceniając całość artykułów Czekalskiego umieszczanych w „Narodowcu”, trzeba powiedzieć, że nie są one przychylne naszemu ustrojowi, ale jednak w zasadzie nie zawierają takich wiadomości, za które można by go pociągnąć z art[ykułu] 22 M[ałego] K[odeksu] K[arnego]. Wiadomości o podobnej treści niejednokrotnie o równie zjadliwej formie możemy spotkać w prasie krajowej, na co w wypadku aresztowania Czekalski niechybnie by wskazał. W tej sytuacji według nas ma rację Prokuratura Wojewódzka w Bydgoszczy, która nie zgodziła się pociągnąć Czekalskiego do odpowiedzialności karnej ${ }^{51}$.

Centrala zalecała obserwowanie „figuranta”, „natomiast walczyć z jego działalnością publicystyczną w chwili obecnej trzeba środkami innymi niż te, które przewiduje kodeks karny". MSW konsultowało sprawę z pracownikami Prokuratury Generalnej, którzy uznali, że Czekalski

do odpowiedzialności karnej może być pociągnięty tylko w wypadku, jeśli w swych korespondencjach przesyłał będzie wiadomości szkalujące PRL, fałszywe lub też stanowiące tajemnicę państwową. Natomiast za sam fakt współpracy z pismem wychodzącym za granicą do odpowiedzialności karnej pociągnięty być nie może ${ }^{52}$.

Do podobnych wniosków doszedł oficer operacyjny Departamentu III MSW niejaki Wojtasik, który na polecenie wicedyrektora podpułkownika Stanisława Filipiaka przeczytał wszystkie artykuły Czekalskiego opublikowane w „Narodowcu” oraz jego

${ }^{50}$ AIPN By., sygn. 070/4111, k. 119-120, Pismo J. Onacika z 8 III 1957 do wiceministra spraw wewnętrznych. W styczniu 1957 wspomniany Czarka doniósł listownie Witoldowi Lasocie, redaktorowi naczelnemu „Ilustrowanego Kuriera Polskiego”, że korespondent bydgoskiego pisma A. Czekalski równocześnie był współpracownikiem emigracyjnego „Narodowca” (w rzeczywistości Czekalski nie współpracował jednak z „Ilustrowanym Kurierem Polskim”). Na początku marca porucznik Paweł Woźny z Wydziału III bydgoskiej SB rozmawiał z Lasotą na interesujące go zagadnienia „,po linii młodzieży”. Przy okazji redaktor bydgoskiego dziennika poinformował oficera SB o liście Czarki i sprawie Czekalskiego. W ten sposób SB uzyskała potwierdzenie informacji o ,wrogiej” działalności korespondenta „Narodowca”, zob.: AIPN By., sygn. 044/288, t. 2, k. 140, List S. Czarki z 20 I 1957 do S. Lasoty; tamże, k. 139, Notatka służbowa P. Woźnego z 7 III 1957.

${ }_{51}$ AIPN By., sygn. 070/4111, k. 121-122, Notatka służbowa A. Czerniaka z 21 III 1957 r.

52 Tamże. 
korespondencję zajętą przez Biuro „W”. Mimo wnikliwej lektury nie znalazł takich fragmentów, które obciążałyby „figuranta”:

Cała trudność - stwierdził - polega na tym, że wszystkie ostrzejsze zwroty w jego artykułach i korespondencji jest obwarowana cytatami z wystąpień towarzyszy Gomułki, Cyrankiewicza i innych oraz całe fragmenty przepisywane są z prasy krajowej. Natomiast jego własnych myśli nie sposób wyodrębnić i sprowadzają się one do b[ardzo] krótkich i zjadliwych komentarzy. Momentów takich, które by zniesławiały członków rządu lub czł[onków] Biura Polit[ycznego] nie dostrzegłem [...], jak również wiadomości z dziedziny tajemnicy państwowej ${ }^{53}$.

Podpułkownik Onacik spodziewał się zapewne innych opinii. Wnioski centrali musiały być dla niego przykrą niespodzianką. Funkcjonariusz SB nie zmienił jednak zdania i szykował kolejne działania.

Gdy w Warszawie badano sprawę Czekalskiego, w Bydgoszczy zapadła decyzja o inwigilacji podejrzanego. Przez trzy dni kilku funkcjonariuszy bydgoskiej SB z Wydziału „B” (pion obserwacji zewnętrznej) obserwowało każdy krok ,figuranta” od jego wyjścia rano do pracy aż do powrotu do domu. Czekalski pracował w Rzemieślniczej Spółdzielni Pracy Kominiarzy w Toruniu. Odnotowano również rysopisy wszystkich osób, z którymi w tym czasie spotkał się „Kulas” (pseudonim nadany Czekalskiemu) oraz wykonano sześć zdjęć. Efekt obserwacji był jednak mizerny. Przygodne rozmowy „figuranta” ze spotkanymi na ulicy znajomymi czy szczegółowe poznanie jego drogi $\mathrm{z}$ domu do pracy (w komunikatach z obserwacji odnotowano numer linii tramwajowej, z której korzystał „Kulas” oraz przystanek, na którym wysiadał) nie miały większej wartości operacyjnej ${ }^{54}$.

Za pośrednictwem redakcji „Narodowca” Czekalski próbował równie nawiązać współpracę z „Kulturą”. Wysłał nawet jakiś artykuł. Tekst się jednak nie ukazał, „gdyż — jak odpisał Jerzy Giedroyc — właśnie ten temat był już szereg razy w «Kulturze» obszernie omawiany". Redaktor paryskiego miesięcznika był jednak bardzo zainteresowany kontaktem $\mathrm{i}$ ewentualną współpracą z Czekalskim ${ }^{55}$. Propozycja zapewne nigdy nie dotarła do adresata, gdyż list Giedroycia z 25 marca 1957 roku przesłany za pośrednictwem „Narodowca” przejęła SB.

$\mathrm{Z}$ dniem 1 kwietnia Czekalski otrzymał wypowiedzenie z pracy, choć przebywał na zwolnieniu lekarskim. Na podstawie zachowanej dokumentacji nie sposób stwierdzić czy przyczyniły się do tego jakieś zakulisowe działania ze strony SB. „Bezpieka” na bieżąco monitorowała jednak sytuację „figuranta” świadectwem czego są „Notatki służbowe" kapitana Trzebuniaka, oficera operacyjnego toruńskiej SB. Funkcjonariusz informował przełożonych, że Czekalski cierpi na dolegliwości reumatyczne i często był nieobecny w pracy. W sprawie swojego zwolnienia Czekalski bezskutecznie interweniował w Zarządzie Spółdzielni Kominiarskich w Warszawie. Na początku maja trafił do szpitala z rozpoznaniem choroby Bürgera (groziła mu nawet amputacja nóg). Aby zdobyć jakieś źródło dochodu zamierzał wraz z żoną założyć hodowlę nutriii ${ }^{56}$.

${ }^{53}$ Tamże, k. 123-124, Notatka służbowa Wojtasika z 29 III 1957.

${ }^{54}$ AIPN By., sygn. 044/288, t. 1, k. 189-193, Komunikaty z 21, 22 i 23 III 1957 z obserwacji obiektu „Kulas”.

55 AIPN By., sygn. 044/288, t. 2, k. 102-103, List administracji „Narodowca” z 26 III 1957 wraz z załączonym listem J. Giedroycia z 25 III 1957 do A. Czekalskiego.

${ }^{56}$ AIPN By., sygn. 070/4111, k. 141, Notatka służbowa S. Trzebuniaka z 17 IV 1957; AIPN By., sygn. 044/288, t. 3, k. 24-25, Notatka służbowa S. Trzebuniaka z 28 IV 1957; AIPN By., sygn. 044/288, t. 1, k. 113, Notatka służbowa S. Trzebuniaka z 17 V 1957. 
Mogło się wydawać, że po opiniach centrali sprawa Czekalskiego przynajmniej na jakiś czas zostanie zamknięta. Stało się jednak inaczej. Kluczowe znaczenie miało zapewne stanowisko podpułkownika Onacika, który nie zamierzał odpuścić „Redaktorowi”. Przypomnijmy, że kilka lat wcześniej zetknął się on już z Czekalskim. W 1948 roku przesłuchiwał go jako podejrzanego za wysyłanie ,szkalujących” artykułów do „Narodowca”. Dziewięć lat później sytuacja znów się powtórzyła. 13 kwietnia 1957 roku oficerowie dochodzeniowi z KW MO w Bydgoszczy major Leon Midro i podporucznik Zdzisław Jadczyk przygotowali plan czynności śledczych w sprawie Adama Czekalskiego. Funkcjonariusze ustalili, że w końcu 1956 roku Czekalski odnowił kontakty z redakcją „reakcyjnego” pisma „Narodowiec” i systematycznie przesyłał drogą listowną „wrogie” i ,antypaństwowe” artykuły, umieszczane w emigracyjnym dzienniku na czołowym miejscu jako korespondencja z Polski. Oceniając „całość artykułów” stwierdzili, że ,szkalowały [one] PRL, bowiem pisane były w formie zjadliwej i tendencyjnie przejaskrawionej, a niekiedy nawet sfałszowanej, co ponad wszelką wątpliwość podrywało autorytet naszej władzy ludowej i Partii w oczach opinii zagranicznej”. Plan przewidywał przeprowadzenie rewizji domowej oraz przesłuchanie podejrzanego ${ }^{57}$.

Coraz wyraźniejsze zaostrzanie cenzury czy pozostawienie na stanowisku wicepremiera „natolińczyka” Zenona Nowaka, ale przede wszystkim własne doświadczenia, wpłynęły na „ochłodzenie” nadziei wiązanych przez Czekalskiego z Gomułką:

Czy na podstawie tego wszystkiego - zastanawiał się w artykule z 23 kwietnia 1957 ro-

ku - można wyciągnąć wnioski, że w Polsce zaczyna się nawrót do niesławnej pamię-

ci rządów socjalizmu stalinowskiego? Czyżby Gomułka przekreślał osiągnięcia pol-

skiego października i wracał do tego, co sam przecież publicznie i jawnie potępił? ${ }^{58}$

W końcu kwietnia prokurator wojewódzki w Bydgoszczy A. Ponulak przedłużył zgodę na zajęcie korespondencji Czekalskiego o kolejne trzy miesiące ${ }^{59}$. Miesiąc później na wniosek KW MO w Bydgoszczy „z uwagi na nowe istotne okoliczności, które wyłoniły się w niniejszej sprawie" prokuratura przedłużyła również dochodzenie przeciwko Czekalskiemu do połowy lipca 1957 roku $^{60}$.

SB usilnie chciała zdobyć materiały obciążające „Redaktora”. W tym celu 22 maja major Leon Midro z KW MO w Bydgoszczy przeprowadził rewizję w domu Czekalskiego. Na żądanie funkcjonariusza SB podejrzany dobrowolnie wydał maszynopisy swoich artykułów, które wysłał do „Narodowca”. Choć w trakcie rewizji nie znaleziono żadnych materiałów „szkalujących PRL”, to „figurant” został zatrzymany i przewieziony do aresztu. Podczas zatrzymania Czekalski stwierdził z ironią, iż „w polskiej demokracji tylko umieją aresztować”, choć miał nadzieję, że po dwunastu latach coś się w tej sprawie zmieniło. Dodał, że jednak ,pomylił się, bo taki sam system istnieje jak w przeszłości”. Oficer „bezpieki” przedstawił mu formalny zarzut, że od jesieni 1956 roku do kwietnia 1957 roku zamieszczał w czasopiśmie „Narodowiec” wydawanym we Francji ,,artykuły w których lżył i wyszydzał ustrój Państwa Polskiego”. Prote-

${ }^{57}$ AIPN By., sygn. 070/4111, k. 131-133, Plan czynności śledczych z 13 IV 1957. Trzy dni później ppor. Z. Jadczyk przygotował formalne postanowienie o wszczęciu dochodzenia przedśledczego; zob.: tamże, k. 134.

${ }^{58}$ A. Czekalski, Konflikty, „Narodowiec” 1957 nr 96, s. 3.

59 AIPN By., sygn. 070/4111, k. 75, Postanowienie Prokuratury Wojewódzkiej w Bydgoszczy z 26 IV 1957 o zajęciu korespondencji A. Czekalskiego.

${ }^{60}$ Tamże, k. 77, Wniosek KW MO w Bydgoszczy z 10 V 1957 o przedłużeniu dochodzenia przeciwko A. Czekalskiemu. 
stując przeciwko bezpodstawnym oskarżeniom Czekalski odmówił złożenia podpisu na postanowieniu o przedstawieniu zarzutów. Po przesłuchaniu prokurator ze względu na stan jego zdrowia nie zgodził się na tymczasowe aresztowanie i nazajutrz po zatrzymaniu Czekalski został zwolniony z aresztu ${ }^{61}$.

W „Notatce” z 25 maja podpułkownik Onacik kolejny raz skrytykował stanowisko Prokuratury Wojewódzkiej w Bydgoszczy, która nie zgodziła się na zastosowanie wobec Czekalskiego aresztu tymczasowego. Zastępca komendanta wojewódzkiego KW MO w Bydgoszczy stanowisko zajęte przez prokuraturę uważał „,za politycznie niesłuszne i niczym nie uzasadnione" ${ }^{\circ 2}$.

W drugiej połowie lipca kapitan Marian Linke, które przejął prowadzenie dochodzenia przeciwko Czekalskiemu, ponownie wystąpił do prokuratury $\mathrm{z}$ wnioskiem o przedłużenie zajęcia korespondencji podejrzanego o kolejne dwa miesiące ${ }^{63}$.

Podczas przesłuchania 23 maja Czekalski zobowiązał się, że nie będzie wysyłał więcej artykułów do „Narodowca”. Groźba procesu i ponownego uwięzienia poskutkowała. Na łamach emigracyjnego dziennika ukazały się jeszcze tylko trzy jego artykuły, w numerach z 24 i 31 maja oraz 14 czerwca, wysłane z kraju jeszcze przed zatrzymaniem. Drukując ostatni tekst redakcja „Narodowca” zaznaczyła, iż „,artykuł ten nadszedł z Polski jeszcze przed zerwaniem się kontaktu z p. Czekalskim”, ${ }^{\text {„4 }}$.

Na początku lipca redaktor i wydawca „Narodowca” Michał Kwiatkowski wyjaśniał czytelnikom, iż „od pewnego czasu” nie nadchodzą korespondencje Czekalskiego z Polski. „Już poprzednio - stwierdził - «ginęły» raz po raz. Nie trudno się domyśleć dlaczego!”. Przypominając, że korespondent „Narodowca” przed kilku laty został skazany na dożywotnie więzienie, dodał, iż „obecny reżim mści się także na nim za jego odwagę i szczerość i widocznie zamyka mu usta. Fakt ten jest dowodem, co znaczy «odwilż» i jaki wpływ mają także dziś stalinowcy w Polsce" ${ }^{\circ 5}$.

Mimo nacisków „bezpieki” Czekalski nie przerwał jednak prywatnej korespondencji z przyjaciółmi za granicą. W liście z 14 lipca dziękował mieszkającemu w Stanach Zjednoczonych Józefowi Bronowiczowi za paczkę odzieżową (,wszystko przyszło w należytym porządku i nic nie brakowało, chociaż paczka została zbebeszona, a następnie przez celników kiepsko związana"). Informował również o swoich problemach zdrowotnych, utracie pracy, zatrzymaniu na 48 godzin oraz grożącym mu procesie. Nawiązując do swoich artykułów w „Narodowcu” stwierdził: „Przedziwne rzeczy dzieją się w naszym biednym kraju. Nawet za popieranie Gomułki w okresie rządów Gomułki idzie się do kryminału. System, system... Inny on nigdzie chyba już na świecie być nie może"66. List oczywiście dostał się w ręce SB.

Ponieważ korespondencja wychodząca i przychodząca na adres Czekalskiego podlegała od stycznia 1957 roku urzędowej kontroli listy w imieniu męża pisała jego żona

${ }^{61}$ Tamże, k. 135, Wniosek z 22 V 1957 o zatrzymanie A. Czekalskiego i przeprowadzenie rewizji; tamże, k. 138-139, Protokół zatrzymania podejrzanego i rewizji osobistej z 22 V 1957; tamże, k. 79, Notatka informacyjna z 23 V 1957; tamże, k. 70, Postanowienie z 23 V 1957 o przedstawieniu zarzutów A. Czekalskiemu; AIPN By., sygn. 044/288, t. 3, k. 22, Meldunek dot. realizacji prowadzonych rozpracowań z $23 \mathrm{~V} 1957$.

62 AIPN By., sygn. 070/4111, k. 159-160, Notatka J. Onacika z 25 V 1957.

${ }^{63}$ Tamże, k. 164, Wniosek KW MO z 19 VII 1957 do Prokuratury Wojewódzkiej w Bydgoszczy o przedłużenie terminu zajęcia korespondencji A. Czekalskiego.

${ }^{64}$ Od Redakcji, Narodowiec 1957 nr 140, s. 1. Ogółem w latach 1956-1957 Czekalski opublikował 56 artykułów na łamach „Narodowca”.

${ }^{65}$ M. Kwiatkowski, Dlaczego milczy Adam Czekalski?, „Narodowiec” 1957 nr 160, s. 1.

${ }^{66}$ AIPN By., sygn. 044/288, t. 1, k. 159, List A. Czekalskiego z 14 VII 1957 do J. Bronowicza. 
Natalia. Mimo braku prokuratorskiej sankcji SB kontrolowało również i jej korespondencję. 27 sierpnia 1957 roku centrala MSW przesłała do KW MO w Bydgoszczy fotokopię listu do Tadeusza Piskorskiego, którego nadawcą była Natalia Czekalska ${ }^{67}$. Od końca listopada 1957 roku korespondencja wychodząca i przychodząca na adres Natalii Czekalskiej była już urzędowo kontrolowana ${ }^{68}$. W lutym 1958 roku prokuratura kolejny raz przedłużyła również zgodę na zajęcie korespondencji Adama Czekalskiego. Po upływie trzymiesięcznego terminu KW MO wystąpiła do prokuratury o zgodę na kontrolę korespondencji „figuranta” do końca lipca. Argumentowano, że Czekalski w dalszym ciągu utrzymywał korespondencję z zagranica ,przy czym istnieje podejrzenie, że w korespondencji tej będzie podobnie jak poprzednio szkalował ustrój PRL" ${ }^{\prime 69}$. Od rewizji w mieszkaniu i zatrzymania w maju 1957 roku Czekalski nie wysyłał już jednak artykułów do „Narodowca”, a jego korespondencja ze znajomymi z Francji czy Stanów Zjednoczonych miała prywatny charakter.

W połowie stycznia 1958 roku do sądu trafił akt oskarżenia przeciwko Czekalskiemu. Prokurator B. Langner oskarżał go o pisanie i przesyłanie do redakcji „Narodowca" artykułów dotyczących życia gospodarczego i politycznego kraju, w których „lżył i wyszydzał ustrój Państwa Polskiego",70.

Mimo grożącego mu wyroku Czekalski nie dał się zastraszyć i złamać SB. Swoją sprawą próbował również zainteresować zagranicznych dyplomatów i dziennikarzy. Na początku czerwca 1958 roku referat „W” (kontroli korespondencji) w Komendzie Powiatowej MO w Toruniu przejął list Czekalskiego do ambasady Francji. Nadawca prosił o przysłanie korespondenta prasy francuskiej w Warszawie na jego proces w toruńskim sądzie. Dodał, że sprawa będzie ciekawa ${ }^{71}$.

W połowie czerwca 1958 roku Czekalski został skazany na trzy lata pozbawienia wolności. W liście do wydawcy i redaktora naczelnego „Narodowca” Michała Kwiatkowskiego z 22 lipca 1958 roku pisał:

cały ten dotychczasowy wyrok uważam za jeden wielki gwałt na sprawiedliwości i na mnie. I to należałoby podkreślić, bo wreszcie trzeba postawić jasne pytanie: czy październik 56 w Polsce jeszcze jest (przynajmniej w pozorach) czy go już zupełnie nie ma i wracamy całym pędem do punktu wyjścia, czyli do okresu wybuchu, a raczej przed wybuchem poznańskim w czerwcu 56. [...] Jedynym popaździernikowym plusem jest tylko to, że mnie z miejsca nie nakazano zaprowadzić do więzienia, chociaż na rozprawie 13 czerwca byli obecni przeważnie sami ubecy w liczbie coś z 15 , sprowadzili sobie nawet kapitana MO i milicjanta w mundurze, tudzież podstawili pod sąd samochód, a wszystko to po to, aby mnie z uciechą zawieźć do kryminału. Sędzia sprawił im zawód. Nacisk na sąd był jednak taki, że chociaż z początku łudziłem się, iż sprawiedliwość weźmie górę, to jednak w dniu rozprawy złudzenia te straciłem ${ }^{72}$.

${ }^{67}$ AIPN By., sygn. 044/288, t. 2, k. 61, Pismo naczelnika Wydziału III Biura „W” MSW z 27 VIII 1957 do naczelnika Wydziału III ds. BP KW MO w Bydgoszczy.

${ }^{68}$ AIPN By., sygn. 044/288, t. 3, k. 21, Postanowienie Prokuratury Wojewódzkiej w Bydgoszczy z 27 XI 1957 dotyczące zajęcia korespondencji na adres N. Czekalskiej.

${ }^{69}$ AIPN By., sygn. 070/4111, k. 92 i 113, Postanowienia Prokuratury Wojewódzkiej w Bydgoszczy z 21 II i 21 V 1958 dotyczące zgody na zajęcie korespondencji na adres A. Czekalskiego.

${ }^{70}$ Tamże, k. 88-91, Akt oskarżenia przeciwko A. Czekalskiemu z 13 I 1958.

${ }^{71}$ AIPN By., sygn. 044/288, t. 2, k. 62. Notatka służbowa ppor. Z. Łobody z 8 VI 1958.

${ }^{72}$ Tamże, k. 125-126, List A. Czekalskiego z 22 VII 1958 do M. Kwiatkowskiego. Ponieważ Czekalski nadal wysyłał listy za granicę w końcu sierpnia 1958. KW MO w Bydgoszczy ponownie wystąpiła do prokuratury o przedłużenie zgody na kontrolę jego korespondencji przez 
Sprawę swojego krajowego korespondenta próbowała nagłośnić redakcja „Narodowca". Wydawany w Lens dziennik informował o protestach przeciw skazaniu Czekalskiego ze strony Polskiego Stronnictwa Ludowego we Francji, ludowców w Wielkiej Brytanii oraz części (przeważnie lokalnej) prasy francuskiej ${ }^{73}$.

$\mathrm{Na}$ początku 1959 roku „Narodowiec” zamieścił obszerny stenogram z czerwcowego procesu Czekalskiego. Kilkanaście dni później wydrukowano również jego francuską wersję. Opublikowano także oświadczenie mało znanej paryskiej agencji prasowej potępiające wyrok na korespondenta „Narodowca"74.

Drastyczny wyrok na Czekalskiego nie wywołał jednak większego rezonansu w emigracyjnej prasie. O ,politycznych porachunkach” i „tragedii” Czekalskiego informował jedynie „prokrajowy” tygodnik „Odgłosy” oraz organ PSL „Jutro Polski”. W tej sprawie milczał londyński „Dziennik Polski i Dziennik Żołnierza” czy „Orzeł Biały”. Powodem był zapewne konflikt generała Władysława Andersa z redakcją „Narodowca” oraz fakt, że wydawany w Lens dziennik sympatyzował ze Stanisławem Mikołajczykiem krytykowanym w ,polskim" Londynie ${ }^{75}$.

W krajowej prasie notka o procesie i wyroku dla „toruńskiego korespondenta emigracyjnego pisma” ukazała się na łamach „Gazety Pomorskiej”,"

Ponieważ „figurant” $\mathrm{w}$ dalszym ciągu przejawiał „wrogą działalność” był nadal rozpracowywany przez SB w ramach sprawy agenturalnej na osobę o kryptonimie „Redaktor”. W ocenie „,bezpieki” jako „,niepoprawny recydywista” był „wybitnie wrogo ustosunkowany do istniejącego w Polsce ustroju" "77.

Korespondent „Narodowca” nie poczuwając się do żadnej winy odwołał się od niesprawiedliwego wyroku. Sąd Najwyższy w Warszawie na posiedzeniu 10 grudnia 1958 roku podtrzymał jednak zarzuty przeciwko Czekalskiemu, ze względu na jego stan zdrowia zmniejszył jedynie karę do dwóch lat więzienia oraz zwolnił go od kosztów postępowania karnego i opłat sądowych. W uzasadnieniu wyroku sędzia K. Czajkowski stwierdził, iż „działanie oskarżonego miało na celu znieważyć, zohydzić i wystawić na pośmiewisko panujący w Polsce ustrój państwowy”. Świadczyć miał o tym „obelżywy i zjadliwy” charakter oraz „wyszydzający ton i forma” artykułów. Sąd nie miał wątpliwości, że Czekalski „działał w zamiarze wyszydzenia i lżenia ustroju Państwa Polskiego. Trafność tego wniosku uzasadniają takie okoliczności, jak to, że oskarżony jest wrogo ustosunkowany do obecnego ustroju i że wiedział o tym, jakie oblicze i kierunek polityczny reprezentuje «Narodowiec»” znany ,jemu i w ogóle ze zjadliwo-

trzy miesiące, tamże, k. 111, Postanowienie Prokuratury Wojewódzkiej w Bydgoszczy z 26 VIII 1958 dotyczące zgody na zajęcie korespondencji na adres A. Czekalskiego.

${ }^{73}$ Protesty przeciw skazaniu redaktora Adama Czekalskiego, Narodowiec $1958 \mathrm{nr}$ 160, s. 1; Oburzenie prasy francuskiej na wyrok przeciw Czekalskiemu, Narodowiec 1958 nr 164, s. 1.

${ }^{74}$ Przebieg komunistycznego procesu przeciw Adamowi Czekalskiemu krajowemu korespondentowi „Narodowca”, Narodowiec $1959 \mathrm{nr} 2$, s. 1-4; Les débats aux procès d'Adam Czekalski suivant le protocol intégral du Tribunal, Narodowiec $1959 \mathrm{nr}$ 20, s. 1, 3, 4; L'Agence Coopérative d'Information de Paris sur la 3-ème condemnation d'Adam Czekalski, correspondent de „Narodowiec” en Pologne, Narodowiec 1959 nr 54, s. 1.

${ }^{75}$ K. L. [Lewkowicz], W imię prawa czy politycznych porachunków, Odgłosy $1958 \mathrm{nr}$ 56, s. 6 (przedruk fragmentów w: Sprawa niesłychanego wyroku komunistycznego na Adama Czekalskiego, Narodowiec 1958 nr 198, s. 3); A. Rubach, Tragedia A. Czekalskiego, Jutro Polski 1959 nr 4, s. 3.

${ }^{76}$ Proces toruńskiego korespondenta emigracyjnego pisma, Gazeta Pomorska 1958 nr 142, s. 2.

77 AIPN By., sygn. 044/288, t. 2, k. 27-32, Plan operacyjnych przedsięwzięć do sprawy agenturalnej na osobę krypt. „Redaktor” z 10 XI 1958. 
ści i napastliwości na panujący ustrój w Polsce”. Wszystko to świadczyło również „o stopniu niebezpieczeństwa społecznego czynu oskarżonego" ${ }^{\text {"78. }}$.

Po uprawomocnieniu się wyroku (Czekalski odpowiadał przed sądem z wolnej stopy), 22 stycznia 1959 roku Sąd Wojewódzki w Toruniu wydał nakaz przyjęcia skazanego do więzienia. Nazajutrz korespondent „Narodowca” został osadzony w więzieniu w Toruniu. Po aresztowaniu „figuranta” SB zakończyła również prowadzenie „sprawy agenturalnej na osobę” przeciwko Adamowi Czekalskiemu. Ponieważ „Redaktor” w swojej „wrogiej działalności” wykorzystywał również żonę, kapitan Zygmunt Grochowski, zastępca komendanta MO w Toruniu, uważał za konieczne w dalszym ciągu stosować inwigilację korespondencji zagranicznej i krajowej Natalii Czekalskiej „w celu kontrolowania treści przesyłanych przez nią listów na adresy ludzi związanych z «Narodowcem»”. Oficer SB ostrzegał, że Czekalska „niewątpliwie takie listy będzie przesyłać, informując redakcję «Narodowca» o swym mężu oraz o sytuacji politycznej i gospodarczej kraju"79.

Aresztowanie schorowanego korespondenta „Narodowca”, pozostawienie go bez należytej opieki i lekarstw równało się wydaniem na niego wyroku śmierci. Już miesiąc później, 23 lutego 1959 roku, Czekalski zmarł w szpitalu więziennym w Grudziądzu. Miał zaledwie 57 lat $^{80}$.

Publicysta „Narodowca” A. Jakubiec, choć nie znał osobiście zmarłego, podkreślił, iż uderzała go

twarda, niezłomna postawa Czekalskiego, jego bezkompromisowość w sprawie ideałów, w imię jakich i dla dobra których się odzywał. Najwyższy szacunek budziła jego stanowczość, jego odwaga w walce ze wszelkim szkaradzieństwem i nieprawością, jakie się panoszyły w Polsce przed wojną, a zwłaszcza po niej, za czasów reżimowych. Nie wiem, czy był ktoś w swej walce o Polskę praworządna i sprawiedliwą bardziej jak on osamotniony i bardziej jak on wytrwały i do ostatka nieugięty ${ }^{81}$.

Redaktor londyńskiego „Jutra Polski” Franciszek Wilk w pożegnalnym nekrologu napisał:

„Wierność swoim przekonaniom, umiłowanie prawa, prawdy i sprawiedliwości przepłacił Czekalski męczeńską śmiercią. Mając do wyboru albo służalcze wysługiwanie się dyktaturze i tyranii za wygodne życie wzorem pewnych dziennikarzy i publicystów krajowych, opływających w dostatki i nagrody, Adam Czekalski wybrał walkę z wrogami wolności i demokracji”, ${ }^{, 2}$.

${ }^{78}$ Tamże, k. 150-153, Odpis wyroku Sądu Najwyższego z 10 XII 1958 w sprawie A. Czekalskiego; Komun[istyczny] Sąd Najwyższy w Warszawie skazat A. Czekalskiego na 2 lata więzienia za pisanie prawdy w ,Narodowcu”, Narodowiec $1959 \mathrm{nr} 2$, s. 1.

79 AIPN By., sygn. 044/288, t. 2, k. 215-217, Raport Z. Grochowskiego z 10 II 1959 do zastępcy komendanta wojewódzkiego MO w Bydgoszczy; tamże, k. 218, Postanowienie z 11 II 1959 o zakończeniu sprawy agenturalnej na osobę kryptonim „Redaktor”.

${ }^{80}$ Adam Czekalski nie żyje! Zamęczono go w więzieniu w Polsce, Narodowiec $1959 \mathrm{nr} 60$, s. 1, 3. Oprócz pożegnalnego artykułu i nekrologu redakcja „Narodowca” na pierwszej stronie zamieściła również duże zdjęcie swojego krajowego korespondenta. Zob. też: Głębokie oburzenie na całym wychodźstwie z powodu zamęczenia śp. Adama Czekalskiego przez siepaczy reżimowych, Narodowiec 1959 nr 63, s. 1 (wbrew tytułowi zamieszczono jedynie głosy kilku, nieznanych szerzej Polaków z Francji).

${ }^{81}$ A. Jakubiec, Ta śmierć oskarża $i$ wydaje wyrok potępienia, Narodowiec $1959 \mathrm{nr}$ 64, s. 1.

${ }^{82}$ F. Wilk, Ś.p. Adam Czekalski, Jutro Polski 1959 nr 6, s. 2. 
Kilka miesięcy później, w numerze jubileuszowym z okazji półwiecza istnienia dziennika, redakcja „Narodowca” wspominała swych zmarłych współpracowników. W tym gronie wymieniono również Adama Czekalskiego „,bohaterskiego korespondenta «Narodowca» w Polsce, trzykrotnie więzionego, katowanego, a jednak niezłomnego aż do chwili swej tragicznej śmierci w lochach bezpieki" ${ }^{83}$.

\section{“AN INCORRIGIBLE RECIDIVIST”. THE NATIONAL CORRESPONDENT OF NARODOWIEC ADAM CZEKALSKI}

In 1958 the court in Torun sentenced Adam Czekalski, the national correspondent of the daily Narodowiec published in Lens in France to 3 years of prison. Czekalski was probably the first person tried after October 1956 for maintaining contacts with an emigration magazine and publishing articles abroad. He was convicted for a similar "crime" some years earlier. Today he is unknown and nearly forgotten, despite being a person of strong character. Ailing, he died in prison, a month after being arrested. He was only 57.

Keywords: Adam Czekalski; Narodowiec (Lens); political repressions in the Polish People's Republic.

${ }^{83}$ Ci, którzy od nas odeszli, Narodowiec 1959 nr 230, s. 24. 